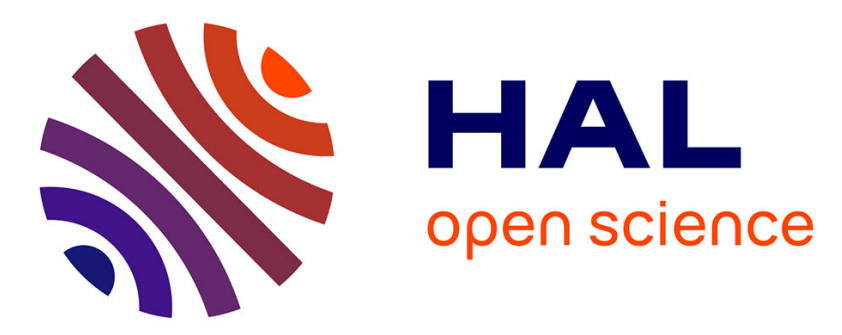

\title{
Activity of the genital tract and plasma levels of oxytocin and cortisol at the time of mating in the ewe
}

Rafael Garcia Villar, D. Schams, M. Alvinerie, M.P. Laurentie, P.L. Toutain, . Station de Pharmacologie-Toxicologie

\section{- To cite this version:}

Rafael Garcia Villar, D. Schams, M. Alvinerie, M.P. Laurentie, P.L. Toutain, et al.. Activity of the genital tract and plasma levels of oxytocin and cortisol at the time of mating in the ewe. Journal of Endocrinology, 1985, 105, pp.323-329. hal-02727693

\section{HAL Id: hal-02727693 \\ https://hal.inrae.fr/hal-02727693}

Submitted on 2 Jun 2020

HAL is a multi-disciplinary open access archive for the deposit and dissemination of scientific research documents, whether they are published or not. The documents may come from teaching and research institutions in France or abroad, or from public or private research centers.
L'archive ouverte pluridisciplinaire HAL, est destinée au dépôt et à la diffusion de documents scientifiques de niveau recherche, publiés ou non, émanant des établissements d'enseignement et de recherche français ou étrangers, des laboratoires publics ou privés. 


\title{
Activity of the genital tract and plasma levels of oxytocin and cortisol at the time of mating in the ewe
}

\section{R. Garcia-Villar, D. Schams*, M. Alvinerie, M. P. Laurentie and P. L. Toutain}

Institut National de la Recherche Agronomique, Station de Pharmacologie-Toxicologie, 180 chemin de

Tournefeuille, 31300 Toulouse, France

*Technische Universität München, Institut für Physiologie, 8050 Freising-Weihenstephan, Federal Republic of

Germany

RECEIVED 7 November 1984

\begin{abstract}
Experiments were conducted in the ewe to determine the effects of mating on the activity of the genital tract and on blood levels of oxytocin and cortisol. The activity of the uterus and cervix was recorded by electromyography, oxytocin was measured by radioimmunoassay, and cortisol by high performance liquid chromatography. Mating itself did not increase circulating oxytocin or cortisol; uterine motility remained
\end{abstract}

unchanged during and after copulation but the cervix was significantly stimulated during teasing and after copulation. It is suggested that increased cervical activity resulting from adrenergic mechanisms may facilitate the generation of a cervical reserve of spermatozoa.

J. Endocr. (1985) 105, 323-329

\section{INTRODUCTION}

Uterine motility, which is almost absent during the luteal phase of the oestrous cycle, increases dramatically at oestrus in the ewe (Naaktgeboren, Van der Weyden, Klopper et al. 1973; Rousseau \& Prud'homme, 1974; Ruckebusch \& Buénọ, 1976; Garcia-Villar, Toutain, Moré \& Ruckebusch, 1982). It has been assumed therefore that uterine contractions play a role in the transport of spermatozoa (Mattner, 1963; Lightfoot \& Restall, 1971). According to several authors (see Overstreet, 1983) a rapid sperm transport occurring within a few minutes of copulation is observed in several species, including sheep. Such rapid transport cannot be explained in terms of the motility of spermatozoa and it has been suggested that mating stimulates release of oxytocin, which enhances uterine contractions and leads to the rapid transport of sperm towards the uterotubal junctions (Harris, 1947; Debackere, Peeters \& Tuyttens, 1961; Fitzpatrick, 1966; Overstreet, 1983). In fact, although early studies provided indirect evidence that oxytocin is released at coitus, because it stimulates uterine motility and milk ejection (for review see Fitzpatrick, 1966) results of direct measurements of circulating oxytocin remain conflicting. Hawker, Roberts \& Walmsley (1959) failed to find oxytocic activity in the plasma of ewes after mating. Debackere et al. (1961) and Roberts \& Share (1969) found oxytocic activity after vaginal stimulation using bioassay methods.

Using a specific radioimmunoassay, Schams, Baumann \& Leidl (1982) were unable to find release of oxytocin in cows after mating with intromission and ejaculation, but they reported that severe dilatation of the vagina is a highly effective stimulus for oxytocin release. On the other hand, there is no general agreement on whether uterine contractility is increased after mating which usually lasts $15 \mathrm{~s}$ or less in sheep. Using pressure recordings, Lehrer, Schindler, Brown \& Fischler (1978/1979) reported that both mating and artificial insemination stimulate uterine motility in the ewe but the stimulatory effect was restricted to the treatment period only. Similarly, Lightfoot (1970) mentioned that mounting produced a "highly characteristic contractile response in both the uterus and cervix', an effect which was not attributed to endogenous oxytocin. Using electromyography (EMG), Garcia-Villar, Toutain \& Ruckebusch (1984a) failed to find any contractile response of the uterus or cervix after copulation and they even reported a short inhibitory response. In the ewe, and using a similar technique, Van der Weyden (1983) showed that non- 
specific environmental stimuli induce 'episodes of activity' (up to 9 min duration), but during mounting itself there is only a short-lasting response of the uterus (up to $1 \mathrm{~min}$ ). These EMG studies agree with the results of Bontekoe, Blacquiere, Naaktgeboren et al. (1977) which support the idea that stressful conditions may lead to either stimulation or inhibition of uterine motility. This suggests that motility changes observed by some authors may be due to a stress response.

The present experiments were designed to evaluate the extent to which the motility of the uterus and cervix could be affected by mating, and whether eventual changes can be attributed to increased oxytocin release, or to the effect of stressful events linked to hand-mating.

\section{MATERIALS AND METHODS}

\section{Animals}

Four ewes and a ram of Lacaune $\times$ Romanof breed were used for these experiments. All animals were adults and weighed about $60 \mathrm{~kg}$. Before surgery, animals were moved indoors, and hay, oats and fresh water were available ad libitum.

\section{Surgical and recording procedures}

The ewes underwent surgery at the beginning of the breeding season (August and September 1983), using aseptic surgical conditions under thiopentone anaesthesia. Pairs of $\mathrm{Ni}-\mathrm{Cr}$ wire electrodes were positioned on the uterine horns and cervix as described by Garcia-Villar et al. (1982). After surgery, the ewes were placed in individual cages and the electrodes were connected to the input panel of a 'direct-writing' EMG amplifier (Reega Minihuit, Alvar, Montreuil, France). As a monitoring procedure, integrated electromyograms (Latour, 1973) of the uterus and the cervix were continuously $(24 \mathrm{~h} /$ day) recorded on potentiometric recorders (CR 553, J. J. Lloyd Instruments, Southampton, Hants) at a low paper speed $(6 \mathrm{~cm} / \mathrm{h})$.

Integrated activity was analysed by an on-line computer, using a Motorola M6800 microprocessor (Garcia-Villar, Toutain \& Ruckebusch, 1984b). The system collected the integrated signal simultaneously in the four ewes (three channels per ewe corresponding to cervix, right and left uterine horns). Arbitrary computer units (one unit corresponding to one volt at the output of the integrator) allowed calculations and statistical analysis.

\section{Oestrous cycle recurrence}

Oestrus was determined according to the well-defined changes in electrical activity observed at this time in the genital tract (Garcia-Villar et al. 1982). The oestrous cycles recurred regularly in all the ewes $(17 \pm 1$ day). Matings occurred during the second half of January 1984 ; i.e. after a period of $18-21$ weeks, during which the ewes became used to handling.

\section{Matings and sàmpling schedules}

Each ewe was mated three times during a period of behavioural oestrus. Intervals between matings were variable, ranging from 5 to $16 \mathrm{~h}$, for each ewe. A catheter, introduced into one jugular vein, remained in situ throughout the oestrous period. At about 30-min intervals, control blood samples were taken from the ewe standing in its cage. Thereafter the ewe, still under recording, was lifted from the cage, fastened only by its collar and allowed to remain quietly for $15 \mathrm{~min}$ or so. A series of blood samples was then taken at 15, 10, 5, 4, 3, 2, 1 and $0 \mathrm{~min}$ before the ram entered the recording room. After entering the room, the ram was allowed to nuzzle the ewe and to attempt false mountings for 3 min during which blood samples were taken every minute from the ewes.

Mounting, with intromission and ejaculation, then occurred. After copulation, the ram was allowed to remain near the ewe for $5 \mathrm{~min}$, and a blood sample was taken from the ewe each minute. Once the ram was removed blood samples were continued but progressively spaced until $25 \mathrm{~min}$ after copulation when the ewe was returned to its cage.

Generally, 20 to 24 samples $(8 \mathrm{ml})$ of blood were taken during each mating session, a total of less than $200 \mathrm{ml}$ blood. Samples were collected into chilled heparinized tubes and centrifuged for $15 \mathrm{~min}$ at $2000 \mathrm{~g}$ at $2-4^{\circ} \mathrm{C}$ within $30 \mathrm{~min}$ of sampling. Plasma samples were stored at $-20^{\circ} \mathrm{C}$ until assayed for either oxytocin or cortisol.

\section{Hormone assays}

Oxytocin

Oxytocin was determined radioimmunologically according to a procedure originally described for bovine samples by Schams, Schmidt-Polex \& Kruse (1979). The method has been improved (Schams, 1983) by using an extraction method with SEP-PAK $\mathrm{C}_{18}$ cartridges (Waters Assoc., Milford, MA, U.S.A.) which also allows concentration of the sample, an antiserum with a higher sensitivity to standard oxytocin, and preparation of the standard curve in buffer. The antiserum, raised in a rabbit, was directed against synthetic oxytocin coupled to bovine thyroglobulin and showed no cross-reaction $(<0 \cdot 1 \%)$ with related peptides, such as vasopressin or anterior pituitary hormones. The lower limit of assay sensitivity was $0.25 \mathrm{fmol} /$ tube, corresponding to $0.25 \mathrm{pmol} / \mathrm{l}$ plasma 
depending on the amount of plasma extracted. The intra-assay coefficients of variation (C.V.) of two control samples run at the beginning, middle and end of the assay were 6.5 and $5.3 \%$. The interassay C.V. of five control samples with low and high oxytocin concentrations varied between 14 and $16 \%$. The $50 \%$ intercept was $2.1 \pm 0.18 \mathrm{fmol}$. The reference preparation (synthetic oxytocin kindly donated by Sandoz, Basle, Switzerland; 200 i.u. $/ \mathrm{ml}$ ) had the same potency as the biological and immunological 4th International Standard from the National Institute for Biological Standards and Control, London.

\section{Cortisol}

Plasma cortisol concentrations were determined by the use of the high performance liquid chromatography method previously described (Alvinerie \& Toutain, 1982). Cortisol was extracted into dichloromethane, after alkalinization of the plasma by $0.1 \mathrm{M}-\mathrm{NaOH}$. Chromatographic analysis was made, using a chromatograph apparatus (Waters Assoc.), a radial compression module device, a universal injector, a $254 \mathrm{~nm}$ UV detector and a recorder. Analyses were performed using a mobile phase of dichloromethane, methanol and acetic acid $94: 4: 0 \cdot 4$ (by vol.) at a flow rate of $1.4 \mathrm{ml} / \mathrm{min}$.

The elution times were 5 and $6 \mathrm{~min}$ for flumethasone (internal standard) and cortisol respectively. Sensitivity was $55 \cdot 2 \mathrm{nmol} / 1$. Average intra-assay variation was $4.9 \%(n=8)$. Variability between days over a week was $8.7 \%(n=5)$. Approximately $16-22$ samples were assayed in a working day by one analyst.

\section{Qualitative evaluation of electromyograms}

Qualitative evaluation of the electrical activity of the genital tract was performed by gross inspection of direct and integrated electromyograms. The occurrence of bursts of spikes was estimated from direct records. The integrated records were used to evaluate a possible modification of the pattern of activity which has previously been defined as alternating regular and irregular activities (Garcia-Villar et al. 1982).

\section{Quantitative analyses and statistics}

The effect of the entrance of the ram into the room, nuzzling and mount-attempts, and copulation with intromission were studied during four successive periods on the three parameters quantitatively assessed (oxytocin, cortisol and genital tract activity). The periods were: (i) control periods, corresponding to the $20 \mathrm{~min}$ preceding the entrance of the ram; (ii) the period from the entrance of the ram to copulation (3-10 min); (iii) a period of $5 \mathrm{~min}$ after copulation; and (iv) a period from 5 to $25 \mathrm{~min}$ after copulation.

Mean plasma concentrations of oxytocin and cortisol for each period were determined by calculating the area under the curve (AUC) by means of the trapezoidal method. The AUC divided by the duration of the period gave the mean plasma concentration. Uterine and cervical activities were rated each minute by the microcomputer and the arithmetic mean for each period was calculated. Effects of periods $(n=4)$, and session of mating $(n=3)$, have been evaluated by factorial analysis of variance.

\section{RESULTS}

All the four ewes were pregnant after the experimental matings. Pregnancies progressed normally and healthy active lambs were born at $146 \pm 1$ days.

\section{Oxytocin}

Individual plasma oxytocin concentrations for the 278 samples ranged from 0.8 to $7.7 \mathrm{pmol} / \mathrm{l}$. The overall mean ( \pm S.D.) obtained from the means of the 12 experimental sessions was $2.7 \pm 1.09 \mathrm{pmol} / 1$. Analysis of variance on mean oxytocin concentration obtained by AUC calculations revealed no significant differences in the mean concentrations before, during and after mating (Table 1). In contrast, a significant $(P<0.001)$ decrease in oxytocin concentrations was observed between the three mating sessions, i.e. $3 \cdot 19 \pm 1 \cdot 27$, $2.38 \pm 1.02$ and $1.86 \pm 0.60 \mathrm{pmol} / 1$ for the first, second and third matings respectively.

TABLE 1. Plasma concentrations of oxytocin and cortisol and level of electromyographic activity of the genital tract: A, control period, i.e. 20 min before entrance of the male; B, from entrance of the male to copulation (3-10 min duration); C, 5 min after copulation; D, from 5 to 25 min after copulation. Values for uterine and cervical activity are expressed as percentage of the corresponding control activity (mean \pm s.D., for the four ewes and the three sessions per ewe)

\begin{tabular}{|c|c|c|c|c|}
\hline & $\mathbf{A}$ & $\mathbf{B}$ & C & D \\
\hline \multicolumn{5}{|l|}{ Parameters (units) } \\
\hline Oxytocin (pmol/l) & $\begin{array}{r}2.58 \\
\pm 1.00\end{array}$ & $\begin{array}{r}2 \cdot 17 \\
\pm 1 \cdot 20\end{array}$ & $\begin{array}{r}2.48 \\
+1.25\end{array}$ & $\begin{array}{r}2 \cdot 68 \\
\pm 1 \cdot 12\end{array}$ \\
\hline Cortisol (nmol/1) & $817 \cdot 0$ & $527 \cdot 2$ & 817.0 & $908 \cdot 0$ \\
\hline & $\pm 620 \cdot 2$ & $\pm 390 \cdot 5$ & \pm 592.6 & $\pm 564 \cdot 7$ \\
\hline $\begin{array}{c}\text { Uterine activity } \\
\text { (\% of control) }\end{array}$ & 100 & $\begin{aligned} & 128 \cdot 0 \\
+ & 50 \cdot 0\end{aligned}$ & $\begin{array}{r}89.0 \\
+17.2\end{array}$ & $\begin{aligned} & 110.0 \\
+ & 22.8\end{aligned}$ \\
\hline $\begin{array}{r}\text { Cervical activity } \\
(\% \text { of control) }\end{array}$ & 100 & $\begin{aligned} & 385.0 \\
\pm & 394.3^{*}\end{aligned}$ & $\begin{aligned} & 188 \cdot 0 \\
\pm & 177.6^{*}\end{aligned}$ & $\begin{aligned} & 108 \cdot 0 \\
+ & 42 \cdot 5\end{aligned}$ \\
\hline
\end{tabular}

$* P<0.05$ compared with control value (analysis of variance). 


\section{Cortisol}

Individual plasma cortisol concentrations varied widely, i.e. from less than $55.2 \mathrm{nmol} / 1$ (detection level) to as much as $2120 \mathrm{nmol} / 1$. The control mean plasma cortisol concentration values obtained while the ewes were still in their cages was $336.7 \pm 316.8 \mathrm{nmol} / \mathrm{l}$. The overall mean of all samples obtained after removing the ewes from their cages was $783 \cdot 3 \pm 452 \cdot 1 \mathrm{nmol} / 1$, the difference being highly significant $(P<0 \cdot 001$, analysis of variance). When only mean plasma cortisol concentrations obtained after removing the ewes were compared there were no significant differences in cortisol before and after mating (Table 1).

Similarly no significant differences in cortisol were found between the three mating sessions, i.e. $753 \cdot 5 \pm 383 \cdot 6,960 \cdot 5 \pm 463 \cdot 7$ and $549 \cdot 2 \pm 405 \cdot 7 \mathrm{nmol} / 1$ for the first, second and third matings respectively.

\section{Activity of the uterus and cervix}

Qualitative aspects

Typical direct and integrated records taken at the time of mating are shown in Figs 1 and 2. The uterus displayed an almost continuous activity of bursts of spikes $(400-600 \mu \mathrm{V} ; 4-10 \mathrm{~s}$ duration) recurring at intervals of 1-3 min. In contrast, the cervix displayed the pattern of activity described previously (GarciaVillar et al. 1982). It consisted of the recurrence, at 40to 60-min intervals, of episodes of regular activity, i.e. short bursts of spikes (up to $500 \mu \mathrm{V} ; 0 \cdot 1-0 \cdot 3 \mathrm{~s}$ duration) occurring in series for 6-8 min (14-17 bursts/min). Short spikes occurred randomly between two episodes.

Gross inspection of the integrated records, taken from $3 \mathrm{~h}$ before to $3 \mathrm{~h}$ after the experimental procedure, indicated that the activity pattern was not qualitatively affected in either the uterus or the cervix.

(a)

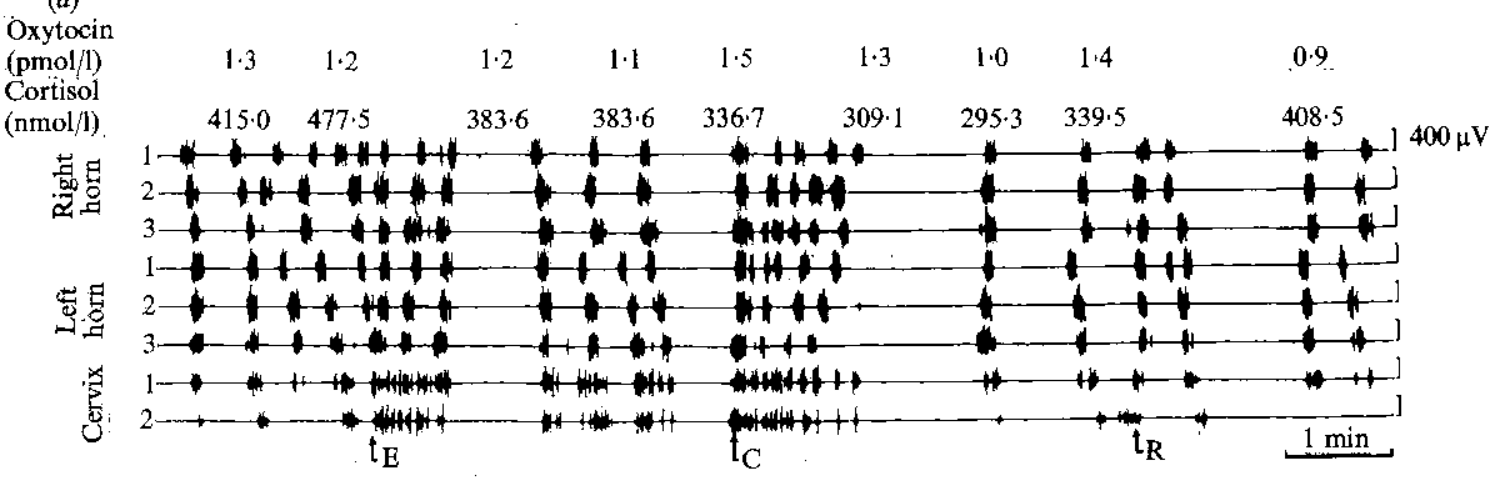

(b)

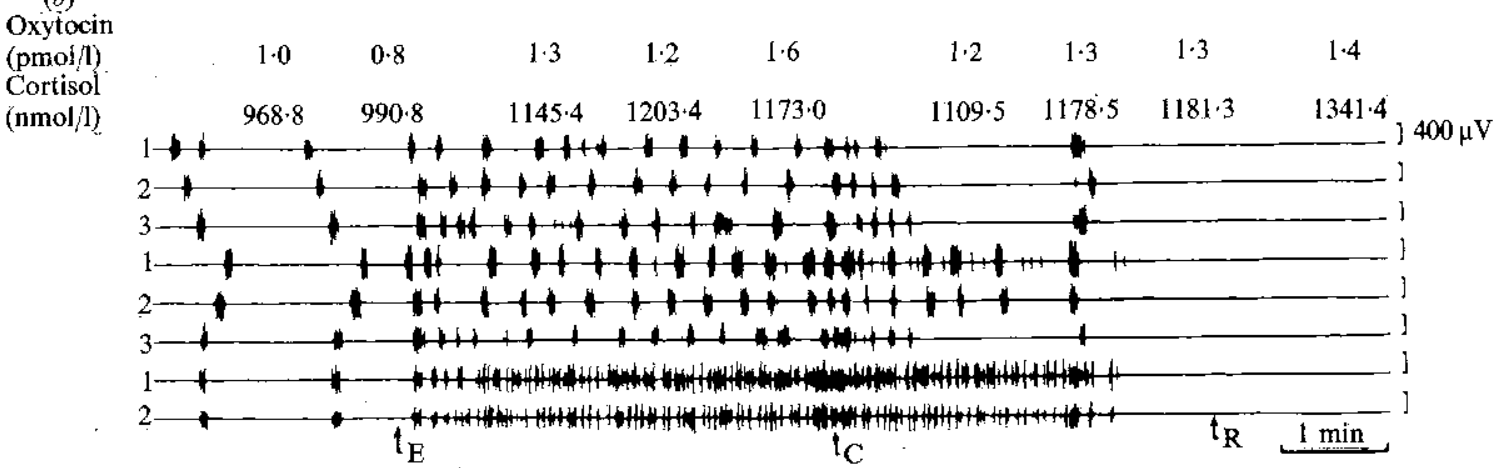

FIGURE 1. Direct electromyograms of the uterus (right and left horns) and cervix, and plasma levels of oxytocin and cortisol in two representative ewes ( $a$ and $b$ ) at the time of mating. In $(a)$ only slight activity responses were recorded after either entry of the $\operatorname{ram}(\mathrm{E})$ or copulation $(\mathrm{C})$. No response was observed on the removal of the ram (R). In $(b)$ entry of the ram induced the onset of an episode of regular activity both on the cervix and the uterus; copulation which occurred within this episode exerted no additional effect; removal of the ram took place during the inhibition which systematically followed regular episodes of activity. No significant changes in the levels of either hormone were elicited by stimuli related to mating in either ewe. 


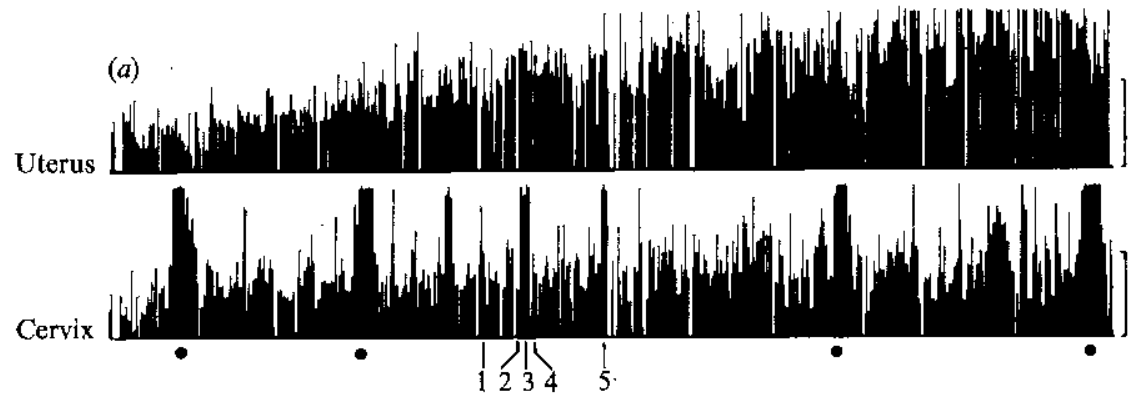

(b)

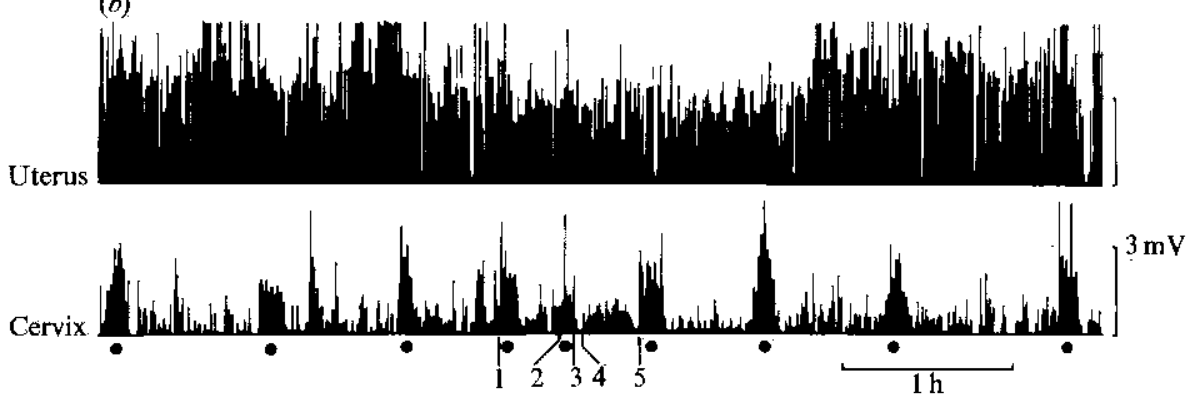

FIGURE 2. Integrated electromyograms of the uterus and cervix at the time of mating in two ewes ( $a$ and $b$ ) with different responses in regard to the occurrence of regular activity episodes (O). In $(a)$ occurrence of the next episode of regular activity was delayed by stimuli (see below) related to mating. In $(b)$ several stimuli induced the onset of an episode of regular activity. Stimuli: 1 , the ewe was removed from the cage; 2 , entrance of the ram; 3 , copulation with intromission and ejaculation; 4 , removal of the ram; 5 , the ewe was returned to the cage.

Nevertheless, non-specific stimuli were able to elicit the onset of a regular episode of activity in the cervix; these included lifting the ewe from the cage (in 6 out of 12 sessions), entry of the male in the recording room $(8 / 12)$ and returning the ewe to its cage $(9 / 12)$. The uterus was less sensitive to these stimuli and a slight activation was seen in only 5 out of 12 sessions, $2 / 12$ and $6 / 12$ for each stimulus respectively. In contrast, neither the cervix nor the uterus were stimulated significantly either after copulation or on removal of the ram.

When the direct records were analysed, the only noticeable event was the almost systematic occurrence of one or a few bursts of spikes, lasting less than $1 \mathrm{~min}$, in both the uterus and the cervix, at the time of intromission and ejaculation.

\section{Quantitative aspect}

The quantitative response to the experimental mating procedures, as measured by the computer, was different for the uterus and for the cervix. Neither teasing nor copulation affected uterine activity (Table 1). This was confirmed by analysis of variance for the different periods considered.

In contrast, an increase in the mean level of activity was detected in the cervix (Table 1) which reflected episodes of activity with an average duration of
$6.42 \pm 0.39 \mathrm{~min}(n=8)$. Analysis of variance confirmed the significant effects $(P<0.05)$ for the first two periods following the entrance of the ram. In all cases, return to control values was achieved within the last period under study, i.e. between 5 and $25 \mathrm{~min}$ after coitus.

\section{DISCUSSION}

The present experiments clearly showed that (i) stimuli related to our experimental conditions and to mating exerted no stress effects; (ii) mating was not accompanied by increased oxytocin secretion; (iii) uterine activity was not altered at the time of coitus though cervical activity was generally increased.

Experimental conditions appear to be critical when the effects of mating, stress and genital tract activity are to be assessed. Indeed, stressful stimuli either increase or inhibit uterine tract activity in sheep, according to the hormonal status (Bontekoe et al. 1977; Van der Weyden, 1983). In the present experiments ewes were prepared surgically approximately 4 months before the actual experiments and recordings were made for $24 \mathrm{~h} /$ day until the mating session. Such a delay allowed the ewes to become accustomed to 
the experimental procedure. Plasma, cortisol was measured during the experimental sessions as it is generally accepted that animals exhibiting higher than normal plasma corticosteroid levels are in a state of stress (Dantzer \& Mormède, 1983). Cortisol values, measured in the present experiment, displayed large and rapid variations as McNatty \& Thurley (1973) have already shown in this species. The important point is the non-significant difference before, during and after mating.

However, cortisol levels were significantly raised after lifting the ewe from the cage, indicating that this procedure led to mild but unavoidable stress unrelated to mating itself. The fact that none of the ewes exhibited obvious behavioural stress and that all ewes became pregnant at the first mating suggests that the experimental conditions approximated physiological conditions.

As in cattle and heifers (Schams et al. 1982), no increase in circulating oxytocin was observed during mating in any of the ewes. Comparison with early studies performed in sheep are difficult because of the difference in analytical techniques (Hawker et al. 1959). However, the fact that the uterus, which displays a high oxytocin responsiveness at the time of mating, is not stimulated indicates clearly that oxytocin does not play a significant physiological role in sperm transport. The same conclusion has been drawn by Thibault \& Wintenberger-Torrès (1967) and Jones (1968). As in cattle (Schams et al. 1982), therefore, it can be stated that copulation in ewes is not able to evoke the reflex secretion of oxytocin, the so-called 'Ferguson' reflex, which has been reported to occur after distension of the vagina (Ferguson, 1941).

In the present experiment mating had no effects on either the level or pattern of activity in the uterus, except for one or a few bursts during intromission. In contrast, at the cervix an episode of regular activity was generally provoked by the arrival of the ram and therefore the cervix remained stimulated at the time of coitus, which generally occurred within $5 \mathrm{~min}$. Lehrer et al. (1978/1979) have reported that mating and artificial insemination stimulate uterine motility but that stimulation is restricted to the treatment period. Similarly, Lightfoot (1970) has observed that mounting produces a highly characteristic contractile response in both uterus and cervix. The response was a sudden rise in tonus, particularly in the cervix. From the above it appears that, to some extent, both the uterus and the cervix can be stimulated at mating. Nevertheless, the stimulation of the uterus does not always occur, and when it does, it is very brief: less than 1 min (our study and Van der Weyden, 1983). In contrast the cervix seems much more easily activated.

Genital tract activation cannot be explained in terms of release of oxytocin since increased release was not detected in the present study and the uterus remained generally non-stimulated or presented a very shortlasting response which, according to Prud'homme \& Rousseau (1982), is probably due to a spinal reflex involving sympathetic fibres.

Activation of the sympathicoadrenal system would explain both activation of the genital tract (Prud'homme, 1984) and differential responsiveness of the uterus and the cervix. Indeed, in the oestrogenprimed ewe it has been shown that the cervix is systematically activated by adrenaline infusion ( $\alpha$ effect) while the uterus shows either partial inhibition ( $\beta$ effect) or activation ( $\alpha$ effect) in response to adrenaline (Garcia-Villar \& Toutain, 1982). In addition, the cervix is more sensitive to behavioural stimuli than the uterus (Lightfoot, 1970). Consequently, sympathetic discharges more easily stimulate the cervix than the uterus.

The physiological significance of the different responsiveness of uterus and cervix to catecholamine remains obscure. However, it is noteworthy that sperm is deposited into the vagina in ruminants and increased motility of this area could be of importance in order to facilitate the transport of sperm, at least from the vagina towards the cervix. In this respect, it has been shown that non-motile spermatozoa are able to ascend through the cervix, but halothane, which inhibits cervical motility, suppresses this phenomenon (Lightfoot, 1970). It can therefore be suggestes that cervical activation at the time of copulation could be relevant in providing cervical reserve of spermatozoa and that this activation was probably not due to an increased release of oxytocin but to sympathetic nervous discharge.

\section{REFERENCES}

Alvinerie, M. \& Toutain, P. L. (1982). Simultaneous determination of corticosterone, hydrocortisone, and dexamethasone in dog plasma using high performance liquid chromatography. Journal of Pharmaceutical Sciences 71, 816-818.

Bontekoe, E. H. M., Blacquiere, J, F., Naaktgeboren, C., Dieleman, S. J. \& Willems, P. P. M. (1977). Influence of environmental disturbances on uterine motility during pregnancy and parturition in rabbit and sheep. Behavioural Processes 2, 41-73.

Dantzer, R. \& Mormède, P. (1983). Stress in farm animals! a need for reevaluation. Journal of Animal Science 57, 6-18.

Debackere, M., Peeters, G. \& Tuyttens, N. (1961). Reflex release of an oxytocic hormone by stimulation of genital organs in male and female sheep studied by a cross-circulation technique. Journal of Endocrinology 22, 321-334.

Ferguson, J. K. W. (1941). A study of the motility of the intact uterus at term. Surgery, Gynecology and Obstetrics 73, 359-366.

Fitzpatrick, R. J. (1966). The posterior pituitary gland and the female reproductive tract. In The pituitary gland, pp. 453-504. Eds G. W. Harris \& B.T, Donovan. London: Butterworths. 
Garcia-Villar, R. \& Toutain, P. L. (1982), Specific drug responses of the uterine cervix in the conscious ewe. In Pharmacologie et toxicologie vétérinaire, pp. 33-36. Les Colloques de l'INRA. Paris: INRA.

Garcia-Villar, R., Toutain, P, L., Moré, J. \& Ruckebusch, Y. (1982). Spontaneous motility of the cervix in cyclic and ovariectomized ewes and changes induced by exogenous hormones. Journal of Reproduction and Ferility 66, 317-326.

Garcia-Villar, R., Toutain, P. L. \& Ruckebusch, Y, (1984a). Patterns of electrical activity of the ovine uterus and cervix from mating to parturition. Journal of Reproduction and Fertility 72, $143-152$.

Garcia-Villar, R., Toutain, P. L. \& Ruckebusch, Y. (1984b). Differential responsiveness to oxytocin of the uterus and cervix in the ovariectomized ewe. Animal Reproduction Science 7, 421-431.

Harris, G. W. (1947), The innervation and actions of the neurohypophysis; an investigation using the method of remote-control stimulation. Philosophical Transactions of the Royal Society Series B 232, 385-441.

Hawker, R. W., Roberts, V. S. \& Walmsley, C. F. (1959). Oxytocin and oxytocic substance in blood extracts before, and following, copulation in sheep. Endocrinology 64, 309-310,

Jones, R. C. (1968). The fertility of ewes injected with synthetic oxytocin following artificial insemination. Australian Journal of Experimental Agriculture and Animal Husbandry 8, 13-14.

Latour, A. (1973). Un dispositif simple d'analyse quantitative de l'électromyogramme intestinal chronique, Annales de Recherches Vétérinaires 4, 437-453.

Lehrer, A. R., Schindler, H., Brown, M. B. \& Fischler, H. (1978/ 1979). The effect of mating, artificial insemination, and fright on uterine motility of the oestrous ewe. Animal Reproduction Science 1, 297-304.

Lightfoot, R, J. (1970). The contractile activity of the genital tract of the ewe in response to oxytocin and mating. Journal of Reproduction and Fertility 21, 376 (Abstract).

Lightfoot, R. J. \& Restall, B. J. (1971). Effects of site of insemination, sperm motility and genital tract contractions on transport of spermatozoa in the ewe. Journal of Reproduction and Fertility 26, 1-13.

McNatty, K. P. \& Thurley, D. C. (1973). The episodic nature of changes in ovine plasma cortisol levels and their response to adrenaline during adaptation to a new environment. Journal of Endocrinology 59, 171-180.

Mattner, P. E. (1963). Spermatozoa in the genital tract of the ewe. II. Distribution after coitus. Australian Journal of Biological Sciences 16, 688-694.
Naaktgeboren, C., Van der Weyden, G. C., Klopper, P. J., Kroon, C. H., Schoof, A. G. \& Taverne, M. A. M. (1973). Electrophysiological observations of uterine motility during the oestrous cycle in sheep. Journal of Reproduction and Fertility 35 , $511-518$.

Overstreet, J. W. (1983). Transport of gametes in the reproductive tract of the female mammal. In Mechanism and control of animal fertilization, pp, 499-453, Ed J. F. Hartmann. New York: Academic Press.

Prud'homme, M. J. (1984). Etude des réponses motrices de l'utérus aux catécholamines chez la brebis sous différentes impregnations stéroïdiennes. Mise en évidence du rôle des catécholamines endogènes. Reproduction, Nutrition et Développement 24, 21-32.

Prud'homme, M. J. \& Rousseau, J. P. (1982). Etude des réponses motrices de l'utérus aux stimulations vaginales et utérines chez la brebis en oestrus. Reproduction, Nutrition et Développement 22 , $597-610$.

Roberts, J. S. \& Share, L. (1969), Effects of progesterone and estrogen on blood levels of oxytocin during vaginal distention. Endocrinology 84, 1076-1081.

Rousseau, J. P. \& Prud'homme, M. J. (1974). Etude électromyographique de la motricité de l'utérus chez la brebis. Action des hormones. Annales de Biologie Animale, Biochimie et Biophysique 14, 67-85.

Ruckebusch, Y. \& Buéno, L. (1976). An electromyographic study of uterotubal activity in the ewe. Journal of Reproduction and Fertility 47, 221-227.

Schams, D. (1983). Oxytocin determination by radioimmunoassay. III. Improvement to subpicogram sensitivity and application to blood levels in cyclic cattle. Acta Endocrinologica 103, 180-183.

Schams, D., Baumann, G. \& Leidl, W. (1982), Oxytocin determination by radioimmunoassay in cattle. II. Effect of mating and stimulation of the genital tract in bulls, cows and heifers. Acta Endocrinologica 99, 218-223.

Schams, D., Schmidt-Polex, B. \& Kruse, V. (1979). Oxytocin determination by radioimmunoassay in cattle 1 . Method and prem liminary physiological data, Acta Endocrinologica 92, 258-270.

Thibault, C. \& Wintenberger-Torrès, S. (1967). Oxytocin and sperm transport in the ewe. International Journal of Fertility 12 , $412-415$.

Van der Weyden, G. C. (1983). Myometrial activity in the nonpregnant Texel ewe. Ph.D. Thesis. Rijksuniversiteit Utrecht, The Netherlands. 
